\title{
EU og Ukraine: Muligheder mod øst
}

Siden murens fald har EU engageret sig $i$ Ukraine. Krisen i det store land mod øst har tydeligjort hvor vigtig EUs østlige grænse er, ikke kun sikkerhedspolitisk, men også i forhold til menneskerettigheder.

EU's forbindelser til Ukraine indledtes allerede 2 uger efter landets selvstændighed i 1991, primært på handelsområdet. Op gennem 1990'erne blev Ukraine anset for en vigtig men 'vanskelig' partner med korrupt samfundssystem, manglende demokrati, en økonomi i sørgelig forfatning og politisk ustabilitet. Ganske vist erklærede den ukrainske rege-ring det allerede i 1994 som sit mål at opnå EUmedlemskab. Men et kritisk indstillet EU over for den 'vanskelige partner' og optaget af den store øst udvidelse samt et Ukraine afhængig af handel med og energiimport fra Rusland blokerede for fremskridt i retning af EU-medlemskab.

I 1998 begyndte Partnerskabs- og Samarbejdsaftalen mellem EU og Ukraine i kraft. Aftalen fokuserede på økonomiske og sociale emner, bedre offentlig forvaltning og sikring af pressefrihed og civile rettigheder.
I 2003 etablerede EU sin naboskabspolitik, som i øst omfattede Ukraine og 5 andre tidligere sovjetrepublikker.

Det Europæiske Råd vedtog den 21.2.2005 en fælles EU/Ukraine- handlingsplan baseret på Partnerskabs- og Samarbejdsaftalen. Og ved aftalens udløb i 2008 indledte EU og Ukraine forhandlinger om en Stabiliserings- og Associeringsaftale.

Associerings- og frihandelsaftalerne indgik som en vigtig bestand-del i det Østpartnerskab, som EU i 2009 indgik med Ukraine og de 5 øvrige østlige nabostater.

EU's forhandlinger med Ukraine om associerings- og frihandelsafta-len blev afsluttet 30.3.2012, hvor aftalen blev initialiseret. Den skal ratificeres af EU's medlemslande, Europa-Parlamentet og Ukraine, før den kan træde i kraft.

Aftalen, der på mere end 1200 sider, hviler på 7 kapitler: Generelle principper, politisk samarbejde og udenrigs- og sikkerhedspolitik, retsvæsen, frihed og sikkerhed, handel, økonomisk samarbejde og sektorsamarbejde, finansielt samarbejde om bl.a. bekæmpelse af svig samt afsnit om institutionelle forhold og generelle og afsluttende bestemmelser. Aftalen kan med rette kaldes et 'pioner'-dokument med en 
hidtil uset bredde og omfang på 28 nøglesamarbejdsområder og dybde (mængden af forpligtelser og tidsfrister).

Til aftalen er der yderligere knyttet 43 annexer, der udpeger den EU-lovgivning, som Ukraine skal overtage på de forskellige områder inden en given dato.

Aftalen har til formål at forstærke udbygning af de politiske og økonomiske forbindelser mellem EU og gradvis integrere Ukraine i EU's indre marked.

Aftalen har særligt focus på grundlæggende reformer, økonomisk genoprettelse og vækst, god regeringsførelse, sektorsamarbejde: energi, transport, miljøbeskyttelse, industrielt samarbejde, social udvikling og beskyttelse, ligestilling, forbrugerbeskyttelse samt uddannelse, ungdom og kulturelt samarbejde.

Aftalen hviler på en stærk bekendelse til værdier og principper: Demokrati, retsorden, respekt for menneskerettighederne og grundlæggende friheder, god regeringsførelse, markedsøkonomi og bæredygtig udvikling. Aftalen lægger også op til styrket samarbejde inden for udenrigs- og sikkerhedspolitik med fokus på regionale emner, masseødelæggelsesvåben, ikke-spredning og nedrustning, konfliktforebyggelse og krisehåndtering.

Det nye 'omfattende og dybe' frihandelsområde mellem EU og Ukraine går også videre end de klassiske frihandelsaftaler, som EU har med en lang række lande. Ud over at gøre hinandens markeder for varer og tjenesteydelser tilgængelige, indeholder aftalen bindende bestemmelser for en gradvis ukrainsk tilnærmelse til EU-standarder og normer inden for handelsområdet og handelsrelaterede områder.

Aftalen indeholder ikke et medlemskabsperspektiv, men anerkender Ukraine som et europæisk land med en europæisk identitet. Aftalen er det mest vidtgående samarbejde, EU tilbyder lande, som ikke har et medlemskabsperspektiv.

Aftalen var klar til underskrift på EU/
Ukraine topmødet 19.12.2012, men EU's udenrigsministre besluttede den 10.12.2012, at Ukraine skulle fremvise konkrete fremskridt vedrørende reform af valgloven, retsordenen og forfatningen, før EU kunne underskrive associerings- og frihandelsaftalen.

Den 21.11. 2013 besluttede Ukraines regering at suspendere forberedelserne til at underskrive associerings- og frihandelsaftalen på topmødet i Østpartnerskabet i Vilnius 28.-29.11. 2013.

Regeringens beslutning blev startskuddet til de store, varige de-monstrationer på Uafhængighedspladsen i Kiev kendt som 'Euromaidan' med deltagelse af oppositionspartierne og et stort antal demonstranter.

\section{EU og omvæltningerne}

Siden demonstrationerne begyndte i Kiev i slutningen af november 2013, har udenrigsrepræsentanten, Catherine Ashton og kommis-særen for udvidelse og naboskabspolitik Stefan Füle besøgt Kiev adskillige gange.

Tilsvarende har et stort antal EU-udenrigsministre og Europaparlamentsmedlemmer besøgt Kiev for at vise støtte og engagement i forhold til en fredelig løsning på konflikten i form af tilbud om mægling og støtte til bestræbelser på at stabilisere situationen.

EU-landenes udenrigsministre og statsog regeringschefer har tillige mødtes ekstraordinært flere gange i løbet af krisen.

Den 10.2.2014 vedtog EU's udenrigsministre rådskonklusioner, der udtrykte dyb bekymring over menneskerettighedskrænkelser, vold, intimidering og kidnapninger. Rådet stillede sig til rådighed for hurtig handling, hvis forholdene i Ukraine forværredes.

På et ekstraordinært møde den 20.2.2014 vedtog EU's udenrigsministre målrettede sanktioner, herunder suspension af eksporttilladelser for udstyr, der kan anvendes til intern undertrykkelse. EU fordømte voldshandlingerne og opfordrede alle parter til at gå i dialog med hinanden.

EU's udenrigsministre trådte atter sammen ekstraordinært den 3.3.2014 og for- 
dømte skarpt Ruslands krænkelse af Ukraines territoriale integritet på Krim og det russiske parlaments bemyndigelse til russisk krigsførelse på ukrainsk jord.

Kommissionen fremlagde den 5.3.2014 en række økonomiske og finansielle støttetiltag som led i en international indsats for at styrke Ukraines politiske og økonomiske reformer.

11 mia. euro kan være til rådighed over de kommende år fra EU-budgettet og EU-baserede internationale finansielle institutioner for at stabilisere den økonomiske og finansielle situation og bistå med overgangen og opmuntre politiske og økonomiske reformer.

På sit møde den 6.3.2014 besluttede Det Europæiske Råd en 3-trins sanktionsraket:

1 trin: Suspendering af forhandlingerne om visumliberalisering og om en ny samarbejdsaftale EU/Rusland samt suspendering af deltagelse i G8-forberedende møder for EU's og de europæiske G8landes vedkommende.

2 trin: Som følge af manglende fremskridt indførelse af målrettede sanktioner mod 21 personer med indrejseforbud og indefrysning af aktiver samt aflysning af EU/Rusland-topmødet og ophør af EU's og Den Europæiske Investeringsbanks aktiviteter i Rusland. EU fordømte kraftigt 'folkeafstemningen' på Krim og anerkender ikke resultatet. Efterfølgende føjet yderligere 12 personer til.

3 trin: Hvis yderligere tilbageskridt: Flere tiltag med betydelige konsekvenser for forholdet mellem Rusland og EU inden for en lang række økonomiske områder.

EU og Ukraine underskrev efterfølgende den 'politiske del' af Associerings- og frihandelsaftalen (præamblen samt titel I og II, dvs. generelle principper samt samarbejdet vedr. FUSP). Selv om der kun er tale om en meget lille del af aftalen, har skridtet stor symbolsk og politisk signaleffekt. Premierminister Jatseniuk kaldte det en historisk dag og det første enorme skridt mod det ultimative mål: EU-medlemskab.
Den økonomiske og handelsmæssige del af aftalen ventes underskrevet efter præsidentvalget 25. maj 2014 - formentlig i juni 2014.

Endelig hilste stats- og regeringscheferne Kommissionens hjælpepakke på 15 mia. dollars velkommen.

Den 11.3.2014 foreslog Kommissionen midlertidigt at fjerne toldafgifter på ukrainsk eksport til EU og dermed fremskynde afsnittet om toldafgifter i Associeringsaftalens del om et dybt og omfattende frihandelsområde og ikke afvente dens ikrafttræden. Dette indebærer en forventet årlig økonomisk gevinst for Ukraine på 500 mio. euro - heraf 400 mio. euro til landbrugssektoren. EU åbner straks for 82,2 pct. af Ukraines landbrugseksport. Øvrige får toldnedsættelser.

Eksisterende EU-afgifter på industrivarer fra Ukraine fjernes straks for 94,7 pct. af produkternes vedkommende - øvrige vil blive reduceret.

Den 26.3.2014 præsenterede kommissærerne Füle og Lewandowski i Kiev en 'Europa dagsorden', som er et politisk/økonomisk styringsredskab til de ukrainske myndigheder og Kommissionen til at forberede Ukraine på gennemførelsen af Associeringsaftalen og hjælpe Ukraine med at tackle og imødegå udfordringer mest effektivt. Senere vil dokumentet være til hjælp med selve gennemførelsen af Associeringsaftalen.

Vejen frem for Ukraine ligger så langt fra fast. Den militære trussel fra det store naboland, stadige manøvrer fra samme for at undergrave den nye ukrainske regerings legitimitet og stabilitet. Det økonomiske mareridt og de særdeles krævende reformer forude. Og en befolkning og en samfundsmæssig sammenhængskraft udfordret politisk, sprogligt, religiøst, erhvervsmæssigt og geografisk mellem nordøst og sydvest.

Rigtig mange forhold kan påvirke Ukraines fremtidige kurs.

Men beslutter Ukraine sig for en fortsat tilnærmelse til EU, kan der overord- 
net opstilles tre (og givet flere men begrænset for overskue-lighedens skyld) mulige udviklingsveje for Ukraine i de kommende år:

- EU-medlemskabsperspektiv,

- Reformeret og styrket Østpartnerskab

- Øst-EFTA og evt. Øst-EEA.

Der ses i den sammenhæng bort fra, at Rusland får presset sit krav igennem om en særdeles vidtgående føderalisering af Ukraine, som de facto vil dele landet i flere delstater med meget vidtgående beføjelser, herunder ret til at føre egen udenrigspolitik! Der lægges så-ledes en fortsat ukrainsk enhedsstat til grund.

Ligeledes lægges til grund, at EU - uanset hvilken udviklingsvej, Ukraine vælger - under alle omstændigheder skal styrke samarbejdet med civilsamfundet og NGO’er i Ukraine. Ved at nå bredere ud end hidtil med information og projektstøtte skal EU fremme en 'dyb demokratisering' og 'europæisering', som kan bidrage til at støbe et solidt fundament under det stadig spæede ukrainske demokrati og dets orientering mod EU.

\section{EU-medlemskabsperspektiv}

I marts 2014 gik EU-landene et skridt videre end hidtil, da man erklærede, at Associerings- og frihandelsaftalen med Ukraine ikke udgør slutstenen i Ukraines forhold til EU. EU udelukkede således ikke et muligt fremtidigt perspektiv om ukrainsk EUmedlemskab - men lovede det på den anden side heller ikke eksplicit.

Tilhængerne af ukrainsk EU-medlemskab læste en åbning herom ind i EU-erklæringen. Modstanderne af ukrainsk EUmedlemskab lagde vægt på, at der intet stod om ukrainsk medlemskab i erklæringen.

EU lider pt. af udvidelsestræthed. Og af konsekvenserne af den langvarige økonomiske krise. Og uklarhed om EU's fremtidige institutionelle arkitektur. Endelig skal alle EUtopposter besættes i år, Europa-Parlamentet skal nyvælges, og Kommissionen skiftes ud.
I den situation har tilhængere af et ukrainsk EU-medlemskabsperspektiv det svært. Omvendt har Ruslands ageren i forhold til Ukraine, ikke mindst på Krim åbnet en række øjne i Europa.

Mod forventning kan der måske således åbne sig et 'mulighedernes vindue' for Ukraine i forhold til EU skabt af den russiske adfærd.

Måske ikke i form af et medlemskabsløfte - i hvert fald ikke på kort sigt. Men om styrkede forbindelser til EU inden for rammerne af et reformeret Østpartnerskab eller i form af et øst-EEA (European Economic Area) på kort sigt. Og dernæst et medlemskabsperspektiv.

Det er værd at erindre, hvor stor en drivkraft og ansporer EU-medlemskabsperspektivet var for de nuværende østeuropæiske EU-medlemmer. Det var udsigten til medlemskab, der fik politikerne til at vedtage og gennemføre meget krævende reformer - og befolkningerne til at stå igennem trange tider med en tro på et 'bedre liv' i EU.

Både tilhængere og modstandere af et ukrainsk medlemskabsperspektiv kan finde hold for deres mening i den situation, Ukraine står i dag.

Med en overhængende militær trussel, en økonomi på kanten af afgrunden og en dybt splittet befolkning kan tilhængerne pege på, at et klart EU-medlemskabsperspektiv på nuværende tidspunkt ville have en opmuntrende virkning på befolkningen ('drømmen om et bedre liv'), styrke den internationale tillid til Ukraine, tiltrække udenlandske investeringer og international finansiel støtte til at klare skærene og afholde Rusland fra militære eventyr med et Ukraine solidt plantet i vesten.

Modstanderne af et EU-medlemskabsperspektiv til Ukraine på nuværende tidspunkt kan hæfte sig ved de ustabile politiske forhold, hvor EU kan komme til at hilse 'brunskjorter' i form af yderligtgående nationalister velkommen.

Videre kan modstandere fremhæve, at 
Ukraine tidligere har været et stort bundløst, korrupt hul, som det ikke er værd at smide penge i, før man har vished for, at korruption, politiske vennetjenester og ineffektivitet er udryddet.

Og modstandere kan anføre, at et EUmedlemskabsperspektiv her og nu kan udløse en russisk militær invasion i Ukraines sydøstlige del for at 'sætte sig på området', inden det er for sent.

Endelig vil modstanderne kunne pege på, at befolkningen ikke entydigt er overbeviste EU-medlemskabstilhængere. Mange - ikke mindst i det sydøstlige Ukraine - frygter, at der i kølvandet på EU-medlemskab følger ulige konkurrence, åbenhed, arbejdsløshed, trussel mod livet og hverdagen, som den er og præference for Rusland frem for EU. Et EU-medlemskabsperspektiv risikerer derfor at skabe frygt og utryghed og dele snarere end samle nationen.

Som det tegner nu, er der ikke stemning i EU for at åbne nye udvidelsesforhandlinger. Og slet ikke midt i vadestedet mellem gammel og ny Kommission, før valget til Europaparlamentet og ny besættelse af de europæiske topposter.

\section{Et reformeret og styrket Østpartnerskab} For tilhængere af et EU-medlemskabsperspektiv kan det derfor vise sig som en mere fremkommelig vej at afsøge mulighederne for at styrke det eksisterende Østpartnerskab. Eller opstille en ny tilknytningsform i form af et øst-EEA.

Et nyt Østpartnerskab kunne rumme alle 6 nuværende medlemmer: Ukraine, Hviderusland, Armenien, Moldova, Aserbajdsjan og Georgien, men operere med flere 'rum' for at tage højde for partnerlandenes forskellige ambitioner og evner til at drive samarbejdet fremad. Og sikre, at EU så vidt muligt ikke 'taber' nogen af partnerlandene.

Ukraine i det forreste rum. Formentlig sammen med Moldova og Georgien, som begge har indgået - men endnu ikke undertegnet en Associerings- og frihandelsaftale med EU.
I næste 'rum' kunne Armenien, som opgav sin færdigforhandlede Associerings- og frihandelsaftale efter russisk pres, Hviderusland, som synes helt stivnet i sin form og Aserbajdsjan, som på lange stræk ikke deler EU's grundlæggende værdier, befinde sig.

For landene i 'rum 2' ville det reformerede Østpartnerskab ikke indebære nogen større substantielle eller synlige ændringer. Landene ville kunne udbygge deres forbindelser til EU efter eget ønske og i den udstrækning, de lever op til EU's krav.

For landene i 'rum 1' ville det nye Østpartnerskab kunne danne ramme om individuelle handlingsplaner for hvert enkelt land på grundlag af deres Associerings- og frihandelsaftaler.

Østpartnerskabet kunne tilbyde landene skræddersyede 'køreplaner' for gennemførelsen af EU's krav, love, standarder og regler - og individuelt udformede tidsplaner herfor. Og tilbyde eksperter og rådgivning fra EU til landene.

Videre kunne Østpartnerskabsrammen udvikles til at lette landenes energimæssige uafhængighed af Rusland og integration i EU's energistruktur.

Og EU kunne tilbyde landene ensidige handelsfordele og bistand i forhold til mulige stridigheder i WTO med Rusland.

Et nyt Østpartnerskab kunne også åbne for hurtigere og mere smidig udbetaling af EU-finansieret støtte til reformprojekter.

Og endelig kunne et reformeret Østpartnerskab hjælpe med at bane vej for visaliberaliseringer, udveksling af studerende og folk til folkkontakter. Østpartnerskabet kunne også bistå NGO-aktiviteter og -kontakter endnu mere aktivt og generøst end i dag.

Den samlede effekt af et sådant reformeret Østpartnerskab kunne være, at landene blev hurtigere stabiliseret, reformeret og 'udvidelsesegnede'.

\section{Øst-EEA eller Øst-EFTA}

Som en ny vision for Østpartnerskabet for de lande, der kan og vil styrke samarbej- 
det med EU, kan Kommissionen få i opdrag til Østpartnerskabstopmødet i Riga i maj 2015 at udarbejde konkrete forslag til et Øst-EFTA eller et Øst-EEA og en 'køreplan' for vejen dertil.

Tyskland, Polen, Sverige og Tjekkiet har allerede leget med tanken om at kopiere det eksisterende Europæiske Økonomiske Område (EEA) til lande i Østpartnerskabet.

Formålet er som for det reformerede Østpartnerskab at stille et at-traktivt og realistisk alternativ til fuldt EU-medlemskab i dag op.

De 4 lande foreslog, at EU styrker sine forbindelser med de enkelte lande i Østpartnerskabet, hvis de gør demokratiske fremskridt.

Og til at styrke forbindelserne forudser landene oprettelse af et fri-handelsområde mellem de 6 lande og EU efter EFTA-modellen (European Free Trade Association) med Island, Liechtenstein, Norge og Schweiz.

Hvis denne model vandt gehør hos de østlige partnere, kunne man eventuelt senere gå videre med et 'Øst-EEA' og styrke forbindelserne yderligere op til det punkt, hvor landenes situation i praksis næsten kun vil adskille sig fra EU-medlemslandenes ved sidstnævntes deltagelse i EU institutionerne. Det ville lette overgangen til egent-ligt medlemskab meget - både for landene selv og for EU.

For Ukraine kunne et Øst-EFTA eller et Øst-EEA formentlig godt være fordelagtigt og repræsentere merværdi. Dels på grund af de åbenlyse økonomiske og handelsmæssige fordele, dels ved de poli-tiske fordele af at blive knyttet endnu tættere institutionelt til EU.

Krisen i Ukraine har understreget, at EU's østlige naboområde er en potentiel krudttønde med lovløshed, autoritære styrer, stenrige oligarker, udbredt fattigdom og frosne konflikter.

EU ønsker stabilitet og sikkerhed i sit østlige naboområde. EU vil forebygge, at problemer med illegal indvandring og flygtninge-strømme, organiseret kriminalitet, forurening og væbnede konflikter i nabolandene overføres til EU. Tjernobyl viste kun alt for tydeligt, at EU ikke kan skærme sig af mod udviklingen i Ukraine.

EU har også interesse i et tæt energisamarbejde med Ukraine og øvrige østlande og i samhandel. Midlerne er hjælp til fremme af demokrati, markedsøkonomi, retssamfund og menneskerettigheder. Gevinsten for EU er et stabilt naboområde, som følger EU's stan-darder bl.a. på handelsområdet.

Begge de formodede favoritter til præsidentposten i Ukraine: Petro Poroshenko og Julia Timosjenko har udtalt sig klart til fordel for vestlig integration og ukrainsk EUmedlemskab. Vinder en af dem som ventet præsidentvalget den 25. maj 2014, kan man derfor se frem til fortsat ukrainsk ønske om og pres for et EU-medlemskabsperspektiv.

Man kan håbe, at EU er sig sit særlige ansvar og sin rolle bevidst, så en udstrakt hånd fra Øst bliver mødt af en hjælpende hånd fra Vest. 